\title{
Plasma Concentrations of Unconjugated Estrone, Estradiol-17 $\beta$ and Estriol, and HCS throughout Pregnancy in Diabetics and Gestational Diabetics ${ }^{*}$
}

\author{
R. De Hertogh, K. Thomas, J. J. Hoet and I. Vanderheyden \\ Unité d'Endocrinologie et de Nutrition, and Physiology of Human Reproduction Unit, Cliniques Universitaires Saint-Pierre, Leuven, \\ Belgium
}

Summary. Plasma unconjugated estrone $\left(\mathrm{E}_{1}\right)$, estradiol-17 $\beta\left(\mathrm{E}_{2}\right)$ and estriol $\left(\mathrm{E}_{3}\right)$, and HCS were measured in the same plasma samples collected throughout pregnancy in 19 gestational diabetics (GD) and 21 diabetics (D). When compared to the results obtained in 22 normal subjects, plasma levels of $E_{1}$ and $E_{2}$ were significantly elevated in $D$ in the second half of gestation. The results were intermediate although closer to the normals, in GD. $\mathrm{E}_{3}$ values were not different from the normals in both $D$ and GD. HCS values were lower than normal in early pregnancy in both $\mathrm{D}$ and GD. In late pregnancy HCS levels were not different from normal in either D or GD, although some individual values were much above the upper limit in some diabetic patients. The hormonal ratios in $\mathrm{D}$ and GD parallel those in normals, although $E_{3} / E_{2}$ and $H C S / E_{2}$ were lower in $D$. These results are discussed with respect to the different behaviour of $E_{2}$ and $E_{3}$, taking into account the difference in their respective biosynthetic pathways. Besides a possible quantitative modification of the placental function in $\mathrm{D}$, the results could tentatively be explained by a qualitative change in the fetal estrogen precursors to placental aromatization, in favour of the 16-non-hydroxylated compound. However, maternal modifications in precursor production or in estrogen metabolism can be an alternative hypothesis. Finally, the present work does not support the hypothetical estrogen deficiency in diabetic pregnancy. Estrogen treatment appears to have no objective justification.

\footnotetext{
* This work was presented at the 11th annual meeting of the E.A.S.D., Munich September 1975 (Abstract 46, Diabetologia 11, 337,1975 ).
}

Key words: Estrone, estradiol, estriol, estrogens, diabetes, pregnancy, HCS, gestational diabetes, plasma levels.

The hormonal environment in diabetic pregnancy has been the subject of many investigations, which have been extensively reviewed recently $[1,2]$. These works were aimed at showing the possible occurrence of endocrine dysfunction of the placenta, induced by the maternal diabetic environment, or of the fetus where adaptative mechanisms might have been stimulated by the particular metabolic situation. Yet, estrogen administration has been advocated as a necessary part of the treatment in diabetic pregnancy [3], in view of inferred hormonal insufficiency based on urine analysis $[1,4]$.

Controversy has arisen concerning the significance of urinary measurements [5], and conflicting results were reported [6]. Plasma measurements of estrogens also gave inconclusive results depending on the technique used, or the selection of patients $[1,4,7]$, regarding for instance their state of equilibrium or the degree of illness. Low [8], high [9-10], and normal [11-15] values were reported for plasma estrogens. High $[16,17]$ and normal $[18,19]$ values were found for plasma HCS (human chorionic somatomammotropin).

In the present study, unconjugated estrogens (estrone, estradiol-17 $\beta$ and estriol) and HCS were measured in the same plasma samples of a group of well treated diabetic pregnancies followed throughout the whole gestational period. Hence, the concomitant variations of these hormones of different origin could be compared to one another, and some insight could be gained into the functional state of the feto-placen- 
Table 1. Clinical data of the insulin-dependent diabetics

\begin{tabular}{|c|c|c|c|c|c|c|}
\hline \multirow[b]{2}{*}{ Number } & \multirow[b]{2}{*}{ Age } & \multirow[b]{2}{*}{$\begin{array}{l}\text { White } \\
\text { Class }\end{array}$} & \multirow[b]{2}{*}{$\begin{array}{l}\text { Delivery } \\
\text { (Weeks) }\end{array}$} & \multicolumn{3}{|l|}{ Neonate } \\
\hline & & & & Weight (g) & Sex & Complications \\
\hline 1 & 21 & $\mathrm{D}$ & 37 & 3,170 & $\mathrm{~F}$ & NO \\
\hline 2 & 26 & B & 38 & 3,500 & $F$ & NO \\
\hline 3 & 19 & $\mathrm{C}$ & 37 & 3,850 & M & S.R.D. \\
\hline 4 & 24 & C & 38 & 3,700 & M & NO \\
\hline 5 & 24 & $\mathrm{C}$ & 37 & 3,110 & $\mathrm{~F}$ & D.C.M. \\
\hline 6 & 32 & B & 37,5 & 4,050 & M & NO \\
\hline 7 & 22 & $B$ & 39 & 3,300 & M & $\mathrm{NO}$ \\
\hline 8 & 24 & B & - & - & - & - \\
\hline 9 & 23 & $\mathrm{D}$ & 38 & 3,250 & $\mathrm{~F}$ & NO \\
\hline 10 & 24 & $\mathrm{C}$ & 37 & 3,250 & $\mathbf{M}$ & NO \\
\hline 11 & 28 & $\mathrm{C}$ & 36 & 3,800 & $\mathbf{M}$ & M.M. \\
\hline 12 & 34 & $\mathrm{D}$ & 37,5 & 3,800 & $\mathbf{M}$ & D.R.T. \\
\hline 13 & 28 & $\mathrm{C}$ & 33 & 1,500 & $F$ & Hy \\
\hline 14 & 33 & $\mathrm{C}$ & 37 & 3,850 & $\mathbf{F}$ & NO \\
\hline 15 & 28 & B & 33,5 & 3,250 & $\mathrm{M}$ & $\mathrm{NO}$ \\
\hline 16 & 23 & $\mathrm{C}$ & 37 & 3,000 & $\mathbf{M}$ & $\mathrm{NO}$ \\
\hline 17 & 24 & $\mathrm{~B}$ & 38 & 3,800 & $F$ & $\mathrm{NO}$ \\
\hline 18 & 29 & $\mathrm{C}$ & 38,5 & 3,150 & $\mathbf{M}$ & $\mathrm{NO}$ \\
\hline 19 & 28 & B & 36 & 3,250 & $\mathbf{M}$ & NO \\
\hline 20 & 29 & $\mathrm{D}$ & 37,5 & 3,290 & $\mathbf{M}$ & NO \\
\hline 21 & 22 & $\mathrm{C}$ & 37,5 & 3,295 & $\mathbf{M}$ & NO \\
\hline
\end{tabular}

$\mathrm{F}=$ female; $\mathrm{M}=$ male; S.R.D. = slight respiratory distress; D.C.M. = death from major cardiac malformation; M.M. = multiple malformations of the locomotor system; D.R.T. = death from renal capillaries thrombosis; $\mathrm{Hy}=$ Hydrocephaly

tal unit in diabetic pregnancies. The diabetic group was compared with a well selected group of normal pregnant subjects, whose detailed findings were reported recently [8].

\section{Material and Methods}

Subjects. - 22 normal subjects (aged 22 to 37 , mean 28 years) served as the control group [20]. The mean time of delivery was $39.4 \pm 1.1$ (SD) weeks after the first day of the last menstrual period. Mean birthweight of the newborn was $3,300 \pm 422$ (SD) g. This corresponded to the 60 th percentile for fetal age and weight, according to Lubchenco [21].

- 19 gestational diabetics (abnormal OGTT during pregnancy ${ }^{1}$ ) were studied as a group. The mean age was 31 years $(20$ to 42 ). They were all treated with intermediate acting insulin (Semi-lente insulin, Novo Industry, $\mathrm{Kbh}$ ) once a day, before noon. 4 of them started the treatment before the tenth week of pregnancy, and received up to 38 Units per day by the end of gestation. 11 patients started between the 10th and the 20 th week, and received up to 26 Units per day. The last four started after the 20 th week and received up to 16 Units per day. The mean time of delivery was $38.8 \pm 1.5$ weeks, and the mean birthweight of the newborn was $3,400 \pm 480 \mathrm{~g}$ (75th percentile of Lubchenco [21]).

All the babies were in good health. Only one of them, born prematurely at 34 weeks and weighing $2,000 \mathrm{~g}$, suffered from transient respiratory problems.

-21 insulin dependent diabetics were studied during pregnancy and reported here as a group. (7 class B of White, 10 class C, and 4 class D). (Some characteristics of these patients and their offspring are given in Table 1). The mean age was 26 years (16 to 34 ). None of them had any evident vascular complications. They were all treated with insulin (regular and long acting) twice or thrice a day. The patients attended the clinic regularly. The diabetic equilibrium was satisfactory in all of them throughout gestation, except for a few short lasting episodes of high blood sugar levels in some of them. Ketonuria was exceptional and occurred in only three patients $\left(\mathrm{n}^{\circ} 3,9,12\right)$. Delivery was induced at $36.9 \pm 1.5$ weeks. The mean birthweight of the newborn was $3,360 \pm 530 \mathrm{~g}$ (90th percentile of Lubchenco [21]). All the babies were born alive. Two babies died in the neonatal period, one from major cardiac malformation $\left(n^{\circ} 5\right)$, the other from multiple thrombosis of the renal capillaries and from hyaline membrane disease $\left(n^{\circ} 12\right)$. One baby exhibited multiple malformations of the locomotor system, but survived $\left(n^{\circ} 11\right)$. One baby was born prematurely at 33 weeks, weighed $1,500 \mathrm{~g}$, and developed some degree of hydrocephaly in the neonatal period, which could be treated $\left(n^{\circ} 13\right)$. One baby had a period of respiratory distress $\left(n^{\circ} 3\right)$. No attempt was made to correlate the outcome of the pregnancies with the hormonal parameters reported below.

Plasma sampling was performed in the morning as described previously [20]. Five to fifteen samples were obtained from each subject during the course of pregnancy.

Estrogen and HCS measurements were performed on the same plasma samples as described previously $[20,22,23]$.

Statistical analysis of the data: mean values were calculated for periods of four weeks in each group. For each time period, each patient was represented by only one value which was the mean of the available results during that period of time. Hence, data from one single patient would not have a preponderant influence in any four week group. Statistical significance of the difference between the normals and the diabetic groups was calculated for each four-weekgroup with the Student " $t$ " Test. 


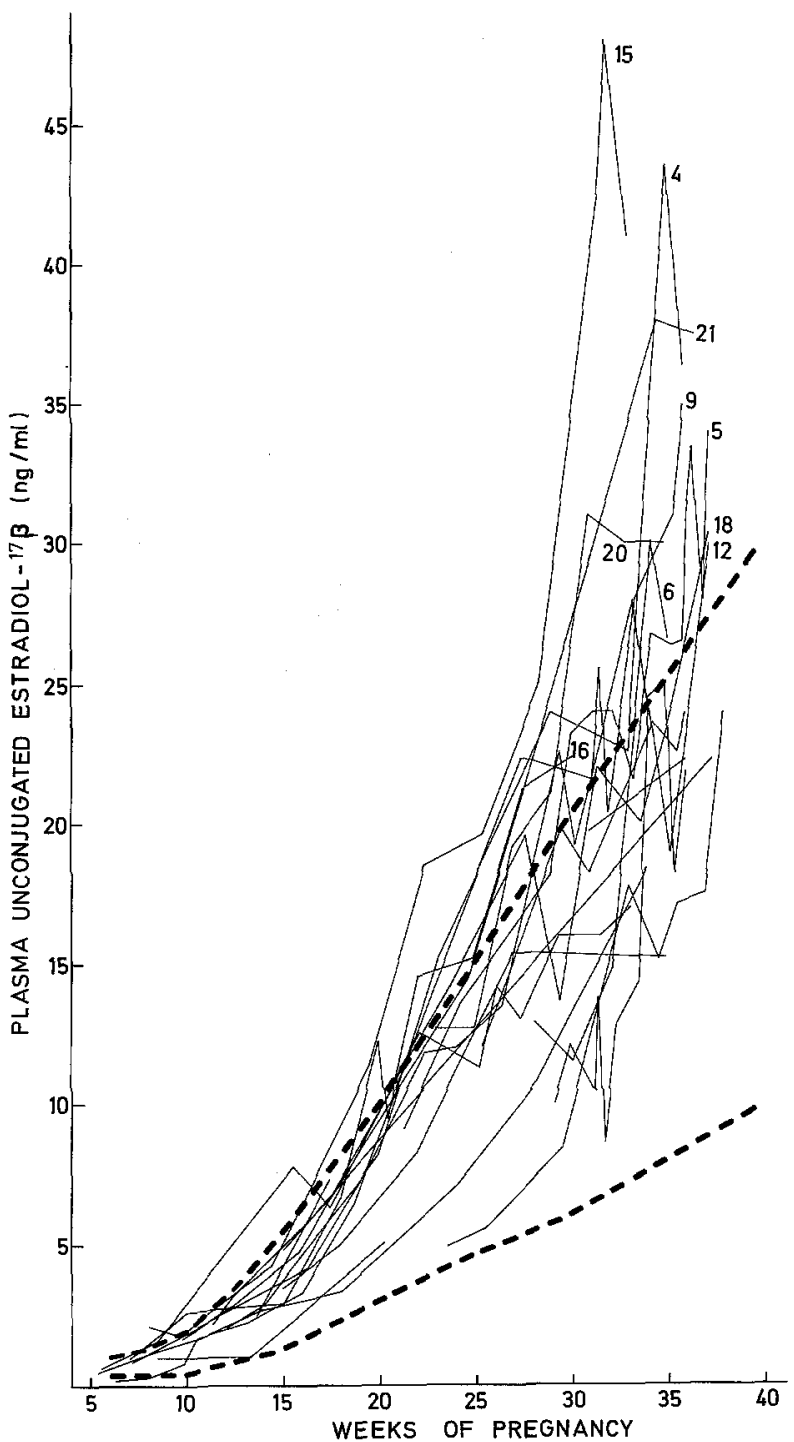

Fig. 1. Plasma levels of unconjugated estradiol-17 $\beta$ in 21 insulin dependent diabetics throughout pregnancy. The heavy lines delineate the dispersion of the control group. (These limits were drawn arbitrarily to include more than $95 \%$ of all the values encountered in the normals. The remaining values fell equally above or below these limits and were scattered throughout the pregnancy period). Gestational age is indicated in weeks elapsed from the first day of the last menstrual period. Patients who exceed the upper limit of the normal are referred to by their numerical order (see Table 1)

\section{Results}

\section{Plasma Unconjugated Estrogens}

In gestational diabetics plasma levels of estrone were distributed between the normal limits, except for a few patients with definitely higher values. Plasma levels of estradiol-17 $\beta$ behaved similarly. Plasma levels of estriol were entirely confined between the normal limits. In the diabetic group, estrone and estradiol-17 $\beta$

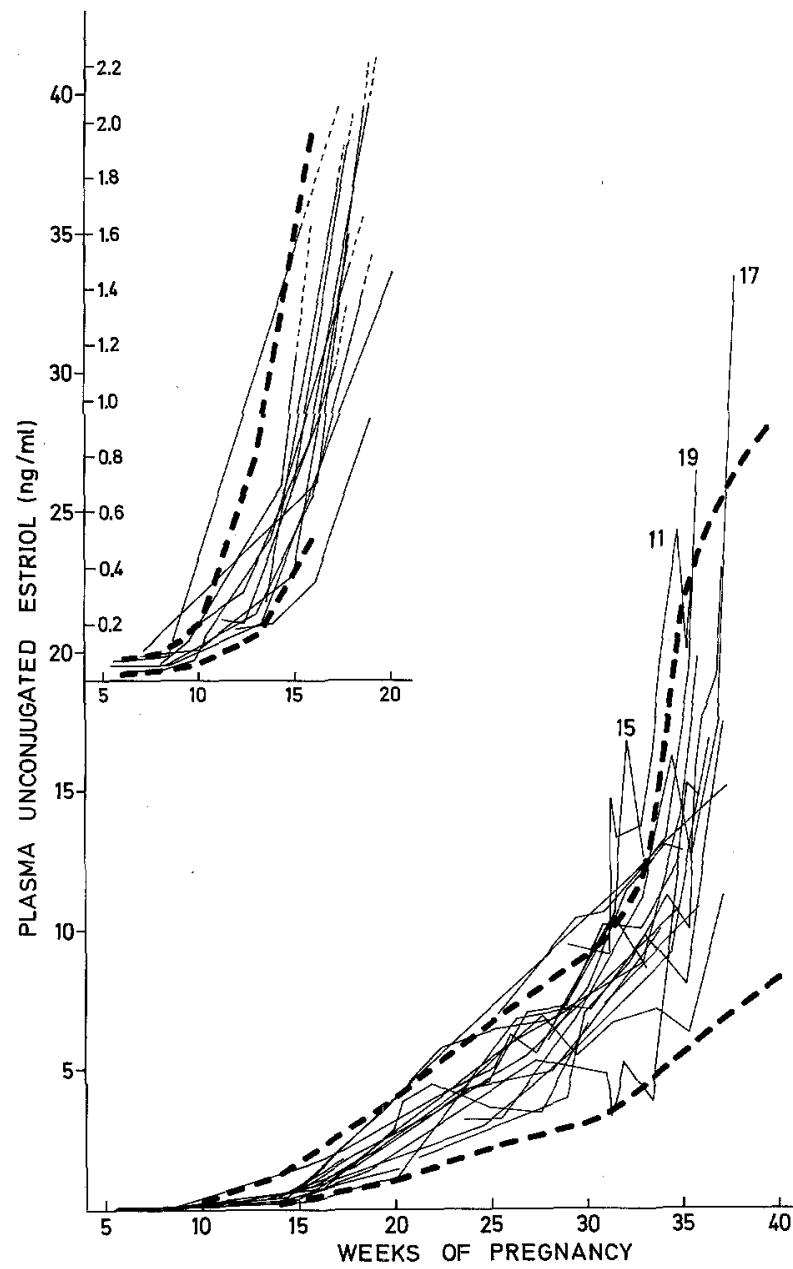

Fig. 2. Plasma levels of unconjugated estriol in 21 insulin dependent diabetics throughout pregnancy. The scale has been enlarged for the first half of pregnancy shown in the upper left of the graph (see legend Fig. 1)

(Fig. 1) levels exceeded the upper limit of normal in several patients. Estriol levels were confined between the normal limits (Fig. 2).

Table 2 gives the mean levels of unconjugated estrogens in the two diabetic groups, compared to the normal group. Estrone and estradiol-17 $\beta$ levels were significantly higher in the pregnant diabetics in the second half of gestation, although the trend was present from the beginning of pregnancy. Estriol values were slightly but not significantly elevated in the last weeks of pregnancy. Gestational diabetics had intermediate mean values for estrone and estradiol-17 $\beta$. Estriol levels were not different from the normals.

Hormonal ratios were calculated from the individual plasma levels of each hormone and mean values were calculated for periods of four weeks as described above. Table 3 shows that estriol to es- 
Table 2. Plasma levels (means $\pm S E M$ ) of unconjugated estrone $\left(E_{1}\right)$, estradiol $\left(E_{2}\right)$ and estriol $\left.E_{3}\right)$, and of human chorionic somatomammotropin (HCS) in a group of 22 normal pregnant subjects $(\mathrm{N})$, and in two groups of pregnant diabetics: 21 insulin dependent diabetics (D) and 19 women with insulin treated gestational diabetes (GD). In brackets: number of subjects included in each four-week mean level

\begin{tabular}{|c|c|c|c|c|c|c|c|c|c|c|}
\hline & & & & & Wee & Pregnancy & & & & \\
\hline & & $5 / 8$ & $9 / 12$ & $13 / 16$ & $17 / 20$ & $21 / 24$ & $25 / 28$ & $29 / 32$ & $33 / 36$ & $37 / 40$ \\
\hline & $\mathrm{N}$ & $\begin{array}{l}0.54 \pm 0.06 \\
(12)\end{array}$ & $\begin{array}{l}0.84 \pm 0.09 \\
(17)\end{array}$ & $\begin{array}{l}1.83 \pm 0.18 \\
(18)\end{array}$ & $\begin{array}{l}3.34 \pm 0.30 \\
(19)\end{array}$ & $\begin{array}{l}4.67 \pm 0.47 \\
(14)\end{array}$ & $\begin{array}{l}5.61 \pm 0.51 \\
(17)\end{array}$ & $\begin{array}{l}5.57 \pm 0.75 \\
(13)\end{array}$ & $\begin{array}{l}6.97 \pm 0.93 \\
(14)\end{array}$ & $\begin{array}{l}8.09 \doteq 1.07 \\
(11)\end{array}$ \\
\hline $\begin{array}{l}\mathrm{E}_{1} \\
\text { (ng/ml) }\end{array}$ & $\mathrm{D}$ & $0.46 \pm 0.08$ & $\begin{array}{l}0.94 \pm 0.12 \\
(6)\end{array}$ & $2.14 \pm 0.27$ & $3.89 \pm 0.44$ & $5.80 \pm 0.62$ & $8.24 \pm 1.16^{\mathrm{a}}$ & $9.70 \pm 1.38^{a}$ & $11.5 \pm 1.37^{\mathrm{a}}$ & $11.1 \pm 1.08$ \\
\hline & $\mathrm{GD}$ & $0.63 \pm 0.10$ & $0.94 \pm 0.31$ & $1.97 \pm 0.42$ & $4.01 \pm 0.79$ & $4.81 \pm 0.60$ & $7.49=1.25$ & $8.80 \pm 1.83$ & $8.46 \pm 1.12$ & $14.1 \pm 4.14$ \\
\hline & $\mathrm{N}$ & $\begin{array}{l}0.81 \pm 0.11 \\
(12)\end{array}$ & $\begin{array}{l}1.63 \pm 0.17 \\
(17)\end{array}$ & $\begin{array}{l}3.30 \pm 0.26 \\
(18)\end{array}$ & $\begin{array}{l}5.60 \pm 0.45 \\
(19)\end{array}$ & $\begin{array}{l}8.48 \pm 0.88 \\
(14)\end{array}$ & $\begin{array}{l}10.8 \pm 0.97 \\
(18)\end{array}$ & $\begin{array}{l}13.0 \pm 1.5 \\
(13)\end{array}$ & $\begin{array}{l}15.4 \pm 1.56 \\
(14)\end{array}$ & $\begin{array}{l}17.8 \pm 1.84 \\
(12)\end{array}$ \\
\hline $\begin{array}{l}\mathrm{E}_{2} \\
(\mathrm{ng} / \mathrm{ml})\end{array}$ & $\mathrm{D}$ & $\begin{array}{l}1.00 \div 0.21 \\
(7)\end{array}$ & $\begin{array}{l}2.10 \pm 0.23 \\
(6)\end{array}$ & $\begin{array}{l}3.73 \pm 0.49 \\
(12)\end{array}$ & $\begin{array}{l}7.07 \pm 0.62 \\
(12)\end{array}$ & $\begin{array}{l}11.7 \pm 1.07^{\mathrm{a}} \\
(13)\end{array}$ & $\begin{array}{l}15.5 \pm 1.36^{b} \\
(13)\end{array}$ & $20.7 \pm 2.22^{b}$ & $\begin{array}{l}25.7 \\
(16)\end{array}$ & $\begin{array}{l}26.9 \pm 2.21 \\
(5)\end{array}$ \\
\hline & GD & $1.07 \pm 0.25$ & $1.62 \pm 0.35$ & $3.74 \pm 0.83$ & $6.53 \pm 0.91$ & $9.50 \pm 1.10$ & $15.0 \pm 1.63^{\mathrm{a}}$ & $14.5 \pm 1.57$ & $16.5 \pm 1.68$ & $24.6 \pm 3.42$ \\
\hline & & & & & & & & & & \\
\hline & $\mathrm{N}$ & $\begin{array}{l}0.074 \pm 0.013 \\
(12)\end{array}$ & $\begin{array}{l}30.16 \pm 0.02 \\
(17)\end{array}$ & $\begin{array}{l}0.76 \pm 0.06 \\
(17)\end{array}$ & $\begin{array}{l}2.29 \pm 0.18 \\
(19)\end{array}$ & $\begin{array}{l}3.97 \pm 0.29 \\
(14)\end{array}$ & $\begin{array}{l}5.07 \pm 0.36 \\
(17)\end{array}$ & $\begin{array}{l}6.45 \pm 0.52 \\
(13)\end{array}$ & $\begin{array}{l}9.76 \pm 1.12 \\
(14)\end{array}$ & $\begin{array}{l}15.8 \pm 2.19 \\
(12)\end{array}$ \\
\hline $\begin{array}{l}\mathrm{E}_{3} \\
(\mathrm{ng} / \mathrm{ml})\end{array}$ & $\mathrm{D}$ & $\begin{array}{l}0.067 \pm 0.010 \\
(7)\end{array}$ & $\begin{array}{l}0.17 \pm 0.02 \\
(6)\end{array}$ & $\begin{array}{l}0.62 \pm 0.11 \\
(12)\end{array}$ & $\begin{array}{l}1.94 \pm 0.22 \\
(12)\end{array}$ & $\begin{array}{l}3.91 \pm 0.23 \\
(13)\end{array}$ & $\begin{array}{l}5.61 \pm 0.33 \\
(13)\end{array}$ & $\begin{array}{l}8.03 \pm 0.61 \\
(16)\end{array}$ & $\begin{array}{l}12.4 \pm 0.91 \\
(16)\end{array}$ & $\begin{array}{l}18.1 \pm 2.45 \\
(5)\end{array}$ \\
\hline & GD & $\begin{array}{l}0.068 \pm 0.010 \\
(7)\end{array}$ & $0.16 \pm 0.03$ & $\begin{array}{l}0.72 \pm 0.12 \\
(11)\end{array}$ & $\begin{array}{l}2.13 \pm 0.30 \\
(12)\end{array}$ & $\begin{array}{l}4.08 \pm 0.51 \\
(12)\end{array}$ & $\begin{array}{l}4.79 \pm 0.50 \\
(14)\end{array}$ & $\begin{array}{l}6.31 \pm 0.83 \\
(12)\end{array}$ & $\begin{array}{l}9.34 \pm 1.12 \\
(16)\end{array}$ & $\begin{array}{l}16.2 \doteq 2.21 \\
(7)\end{array}$ \\
\hline & $\mathbf{N}$ & $\begin{array}{l}0.068 \pm 0.018 \\
(10)\end{array}$ & $\begin{array}{l}30.24 \div 0.03 \\
(19)\end{array}$ & $\begin{array}{l}0.76 \pm 0.06 \\
(18)\end{array}$ & $\begin{array}{l}1.50 \pm 0.10 \\
(20)\end{array}$ & $\begin{array}{l}2.64 \pm 0.19 \\
(14)\end{array}$ & $\begin{array}{l}3.46 \pm 0.22 \\
(17)\end{array}$ & $\begin{array}{l}4.83 \pm 0.30 \\
(14)\end{array}$ & $\begin{array}{l}5.16 \pm 0.40 \\
(12)\end{array}$ & $\begin{array}{l}5.79 \pm 0.57 \\
(12)\end{array}$ \\
\hline $\begin{array}{l}\mathrm{HCS} \\
(\mu \mathrm{g} / \mathrm{ml})\end{array}$ & $\mathrm{D}$ & $\begin{array}{l}0.036 \pm 0.008 \\
(5)\end{array}$ & $\begin{array}{l}30.15 \pm 0.03 \\
(6)\end{array}$ & $\begin{array}{l}0.55 \pm 0.05^{a} \\
(12)\end{array}$ & $\begin{array}{l}1.03 \pm 0.11^{\mathrm{b}} \\
(12)\end{array}$ & $\begin{array}{l}1.97 \pm 0.15^{a} \\
(12)\end{array}$ & $\begin{array}{l}3.25 \pm 0.16 \\
(14)\end{array}$ & $\begin{array}{l}5.24 \pm 0.74 \\
(15)\end{array}$ & $\begin{array}{l}6.96 \pm 0.93 \\
(15)\end{array}$ & $\begin{array}{l}6.14 \pm 1.55 \\
(5)\end{array}$ \\
\hline & $\mathrm{GD}$ & $\begin{array}{l}0.078 \pm 0.041 \\
(3)\end{array}$ & $\begin{array}{l}0.24 \pm 0.06 \\
(8)\end{array}$ & $\begin{array}{l}0.59=0.08 \\
(11)\end{array}$ & $\begin{array}{l}0.83 \pm 0.13^{b} \\
(11)\end{array}$ & $\begin{array}{l}2.16 \pm 0.20 \\
(12)\end{array}$ & $\begin{array}{l}2.98 \pm 0.35 \\
(13)\end{array}$ & $\begin{array}{l}3.91 \pm 0.37 \\
(11)\end{array}$ & $\begin{array}{l}5.32 \pm 0.35 \\
(14)\end{array}$ & $\begin{array}{l}5.35 \pm 0.61 \\
(7)\end{array}$ \\
\hline
\end{tabular}

Statistical significance against normals: ${ }^{\mathrm{a}} \mathrm{p}<0.05,{ }^{\mathrm{b}} \mathrm{p}<0.01$

tradiol $-17 \beta$ ratio was significantly lower in diabetics in many time periods. Gestational diabetics again fell between the normal group and the diabetic group.

\section{Plasma HCS}

Almost all values of $\mathrm{HCS}$ were included within the normal range except for a few elevated levels in the diabetic group (Fig. 3). Mean levels (Table 2) were not different from the normal except for somewhat lower values in the first half of gestation in the pathological groups.

The HCS to estradiol-17 $\beta$ ratio (Table 3 ) was lower in the pathological groups. The HCS to estriol ratio was lower, although not significantly, in the early weeks of pregnancy in the diabetic group only.

\section{Discussion}

The simultaneous measurements of plasma unconjugated estrogens (estrone, estradiol and estriol) and of HCS in normal subjects have allowed a better understanding of the sequence in which the multiple endocrine functions intervene to produce the hormonal environment in the pregnant women [20]. It was shown that the early estradiol increase which follows the implantation was enhanced, by the 8 th week of gestation, as a result of the developing endocrine function of the placenta. By that time also, HCS rapidly increased in maternal plasma. Estriol increase occurred between the tenth and the twelfth week as a result of the endocrine activity of the fetal adrenals [20].

A similar sequence of events was found in the first half of diabetic pregnancies. Indeed, the fluctuations of unconjugated plasma estrogens were parallel to those of the control group, although estradiol levels were slightly but not significantly higher in diabetics. Estriol to estradiol ratio was, however, decreased in diabetics. Plasma HCS was lower in diabetics in early pregnancy, and the increase was rather delayed. Although this has not been commented upon before, published results [3] appear to correspond with this observation, but the explanation is not clear. Sustained hyperglycaemia may reduce HCS levels in normal subjects [24-25]. Our diabetic subjects, however, were well controlled and not in a state of constant hyperglycaemia. Hence, hyperglycaemia does not seem to adequately explain this finding, which may be 
Table 3. Means \pm SEM of hormonal ratios calculated from individual plasma levels of unconjugated estrone $\left(\mathrm{E}_{1}\right)$, estradiol $\left(\mathrm{E}_{2}\right)$ and estriol $\left(E_{3}\right)$, and of HCS throughout pregnancy.

$\mathrm{N}=$ normals. $\mathrm{D}=$ insulin dependent diabetics. $\mathrm{GD}=$ women with insulin treated gestational diabetes.

In brackets: number of subjects in each four-week mean value



Statistical significance against normals: ${ }^{\mathrm{a}} \mathrm{p}<0.05,{ }^{\mathrm{b}} \mathrm{p}<0.01$

linked with the functional state of the developing placenta.

In the second half of pregnancy, the increase in unconjugated estrone and estradiol was definitely higher in diabetics. Although this had not been revealed in cross-sectional studies of diabetic and normal subjects [14], the difference was highly significant in the present longitudinal study of well selected groups. However, the level of unconjugated estriol was not different from the normals in our study, in accordance with others [12]. The estriol to estradiol ratio was significantly lower in diabetics, as well as the HCS to estradiol ratio.

The increase in plasma estradiol in diabetics, while estriol values remain normal, is not easily understood. The aromatization capacity of the diabetic placenta has been found to be reduced [26, 27] or normal [28] in vitro. In vivo, low [29] or normal [30] aromatization of dehydroepiandrosterone (DHA) has been reported. Our results do not indicate any trend to decreased aromatization. However, the dissociation between the respective behaviour of estradiol and estriol cannot be explained by a single quantitative modifica- tion of placental aromatization secondary, for instance, to increased placental mass. The availability of the estrogen precursors appears to be qualitatively modified in diabetic pregnancy. Indeed, it should be recalled that maternal DHA still contributes to about $50 \%$ of the estradiol produced by the placenta at the end of pregnancy, whereas estriol originates from fetal DHA for up to $90 \%$ [30] after $16 \alpha$ hydroxylation by the fetal liver [31, 32]. Increased estradiol could then be produced by a sustained increase of the maternal adrenal function. This eventuality has not been documented $[1,33]$. Hyperfunction of the fetal adrenals $[1,33,34,35]$ would increase estradiol, only if associated with a relative lack of the $16 \alpha$ hydroxylating activity of the fetal liver. A deficit of $16 \alpha$ hydroxylated compounds was found in the urine of one newborn of a diabetic mother [36]. The low pregnandiol excretion [1] in the presence of normal or high maternal plasma progesterone in diabetic pregnancy $[37,38]$ might also result from fetal liver insufficiency [1]. However, those observations and ours do not provide direct evidence of a fetal anomaly in the hepatitic hydroxylating activity, although they suggest 


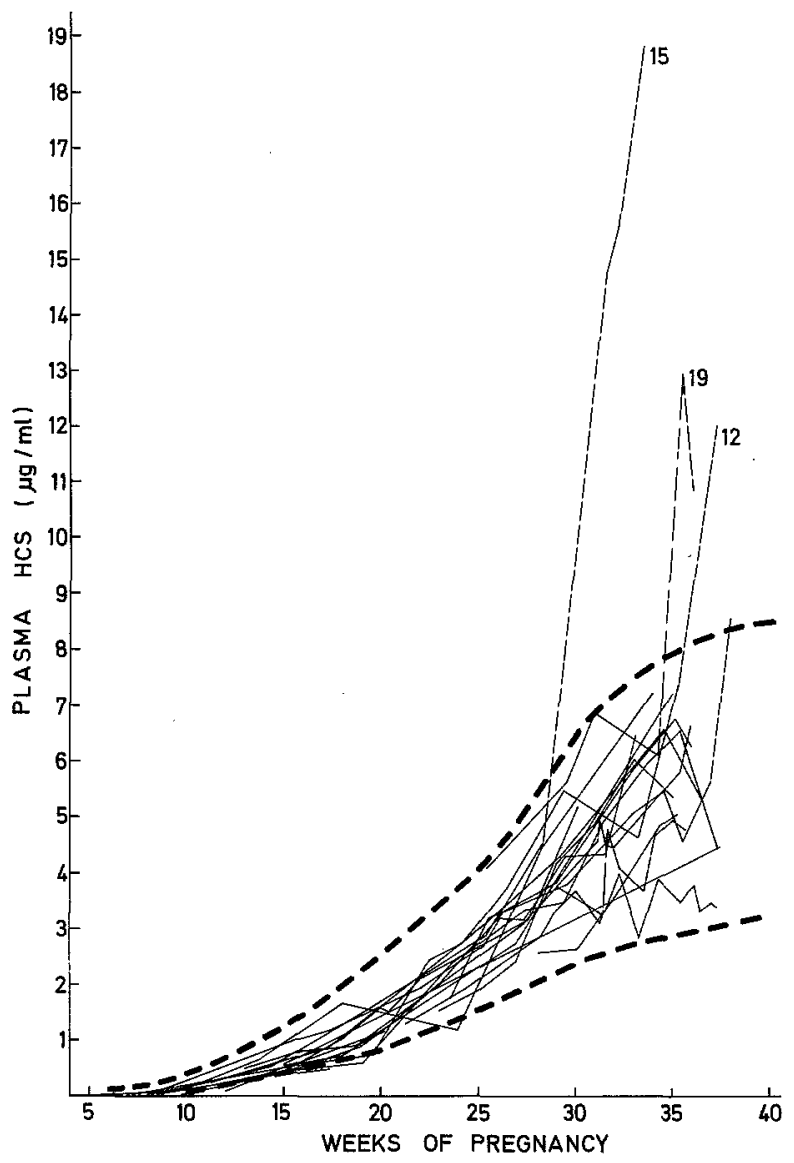

Fig. 3. Plasma levels of HCS in 21 insulin dependent diabetics throughout pregnancy (see legend Fig. 1)

that some disturbance exists in the fetal compartments in either the production of estrogen precursors, their metabolism or their delivery to the placenta.

Another interpretation of our results could implicate the maternal metabolism of estrogens. A reduced clearance of unconjugated estrone and estradiol, and to some extent of estriol, could explain the lower levels of urinary estrone and estradiol [1], and of plasma conjugated estriol [8] as reported by some authors, so also the higher levels of plasma unconjugated estrone and estradiol reported here. However, normal [11] or high [9] levels of plasma conjugated estriol have also been reported, as well as high levels of urinary estrogens [6]. Nevertheless, the metabolism of estrogens in diabetes is still poorly understood and deserves further study.

The HCS levels were normal in all our patients in the second half of gestation, except for a few higher values. Recent data confirm the normal fluctuation of HCS in well controlled diabetics $[18,19]$. In the present study, consistent with others [19], the high values were found concomitantly with episodes of poor diabetic stability.

In gestational diabetics, the trend in the estrogen levels was towards an increase, as in the diabetics, although the differences were not significant. In this group, as in the diabetics, there was no evidence of any estrogen insufficiency, as far as the maternal environment was concerned. Hence, our present data do not provide any physiopathological support to therapeutic estrogen administration to the mother at any time of gestation.

Finally, of practical importance is the usefulness of the measurement of plasma estrogens and HCS in determining the management of diabetic pregnancy. The present study was not aimed to answer this question.

The figures show the dispersion of the individual levels, as well as the variations in individual subjects. Hence, more cases and a wider variety of clinical situations are needed before the practical value of one or a few determinations in any single patient could be ascertained. The higher levels of estradiol in the second half of well equilibrated diabetic pregnancies would have to be taken into account when referring to a "normal" range in this period of gestation. In this respect, plasma unconjugated estriol, which was normal in the diabetic group, may prove to be more satisfactory.

Whether hormonal ratios obtained by simultaneous determinations of several variables (estradiol, estriol and HCS) in the same plasma sample would constitute a practical tool in the management of complicated pregnancy is unanswered at the present time.

1. OGTT: Oral glucose tolerance test was performed with $100 \mathrm{~g}$ glucose. Venous blood glucose was determined at $0,30,60,120$ and 180 minutes after ingestion. OGTT was considered abnormal when two points exceeded the following values: $90-160-150-120-100$ $\mathrm{mg} / 100 \mathrm{ml}$ at the respective times. The OGTT was performed as a screening procedure for carbohydrate intolerance, because of familial history of diabetes or personal history suggestive of gestational diabetes (macrosomia, perinatal mortality, glycosuria, hydramnios, fetal malformation, excess weight gain).

When gestational diabetes (abnormal OGTT) was found, the patient was put on diet with or without insulin treatment, depending on the past history or the actual degree of carbohydrate intolerance. Only those gestational diabetics who were treated with insulin were included in this study.

The normal group consisted of women having no familial or personal history suggestive of gestational diabetes. OGTT were not performed in these subjects.

Acknowledgments. We acknowledge the gift of estrogen antibodies from Dr. R. Vande Wiele (Columbia University, New York), I. Thorneycroft (University of Southern California, Los Angeles), and H. R. Lindner (Weizmann Institute, Rehovot). The skillful technical assistance of J. Hennaux and J. Biernaux have been greatly appreciated. The authors are indebted to the Fonds National de la Recherche Scientifique, the Fonds de la Recherche Scientifique Médicale and the Ford Foundation, U.S.A., grant n $n^{\circ} 6600425$ for their financial support. 


\section{References}

1. Lyngbye, J.: Oestrogen metabolism in diabetic pregnancy. Dan med. Bull. 17, 173-189 (1970)

2. Gillmer, M. D. G., Beard, R. W.: Fetal and placental function test in diabetic pregnancy. In: Carbohydrate metabolism in pregnancy and the newborn (eds. H. W. Sutherland, J. M. Stowers), pp. 168-194. Edinburgh: Churchill Livingstone 1975

3. Selenkow, H. A., Varma, K., Younger, D., White, P., Emerson, K.: Patterns of serum immunoreactive human placental lactogen (IR-HPL) and chorionic gonadotropin (IR-HCG) in diabetic pregnancy. Diabetes 20,696-706 (1971)

4. Van Leusden, H. A.: Hormonal changes in pathological pregnancy. Vitam. and Horm. 30, 281-361 (1970)

5. Cohen, S. L.: The excretion of labile oestrogens during human pregnancy. Acta endocr. (Kbh.) 67, 687-697 (1971)

6. Easterling, W. E., Talbert, L. M.: Estriol excretion in normal and complicated pregnancies. Amer. J. Obstet. Gynec. 107, 417-422 (1970)

7. Lindberg, B. S., Johansson, E. D. B., Nilsson, B. O.: Plasma levels of non conjugated oestradiol-17 $\beta$ and oestriol in high risk pregnancies. Acta obstet. gynec. scand. Suppl. 32, 37-51 (1974)

8. Masson, G. M., Sutherland, H. W.: Plasma oestriol in pregnancy complicated by diabetes mellitus. J. Obstet. Gynaec. Brit. Cwlth 80, 536-541 (1973)

9. Levitz, M., Selinger, M.: Plasma oestriol levels in class D diabetes of pregnancy. Amer. J. Obstet. Gynec. 108, 82-84 (1970)

10. Svendsen, R., Sorensen, B.: The concentration of unconjugated oestrone and $17 \beta$-oestradiol in plasma during pregnancy. Acta endocr. (Kbh.) 47, 237-244 (1964)

11. Nachtigall, L., Bassett, M., Hogsander, U., Levitz, M.: Plasma estriol levels in normal and abnormal pregnancies: An index of fetal welfare. Amer. J. Obstet. Gynec. 101, 638-648 (1968)

12. Cleary, E., Young, P. C. M.: Serum unconjugated estriol in normal and abnormal pregnancy. Amer. J. Obstet. Gynec. 118 , 18-24 (1974)

13. Roy, E. J., Kerr, M. G.: The concentration of oestrogens in the peripheral blood of the pregnant diabetic woman. J. Obstet. Gynec. 71, 106-111 (1964)

14. De Hertogh, R., Thomas, K., Hoet, J. J., Ekka, E.: Plasma levels of unconjugated estrogens in normal and diabetic pregnancies. Amer. J. Obstet. Gynec. 117, 1076-1079 (1973)

15. Klopper, A., Sutherland, H. W.: Hormones of the feto-placental unit in diabetes. In: Carbohydrate metabolism in pregnancy and the newborn (eds. H. W. Sutherland, J. M. Stowers), pp. 58-66. Edinburgh: Churchill Livingstone 1975

16. Spellacy, W. N., Buhi, W. C., Birk, S. A., McCreary, S. A.: Distribution of human placental lactogen in the last half of normal and complicated pregnancies. Amer. J. Obstet. Gynec. 120, 214-223 (1974)

17. Wiese, J., Molsted-Pedersen, L., Lebech, P. E.: Human chorionic somatomammotropin in diabetic pregnancies. Acta endocr. (Kbh.) Suppl. 182, 44-51 (1974)

18. Lindberg, B. S., Nilsson, B. A.: Human placental lactogen (HPL) levels in abnormal pregnancies. J. Obstet. Gynec. Brit. Cwlth. 80, 1046-1053 (1973)

19. Cohen, M., Haour, F., Dumont, M., Bertrand, J.: Prognostic value of human chorionic somatomammotropin plasma levels in diabetic patients. Amer. J. Obstet. Gynec. 115, 202-210 (1973)

20. De Hertogh, R., Thomas, K., Bietlot, Y., Vanderheyden, I., Ferin, J.: Plasma levels of unconjugated estrone, estradiol and estriol and of HCS throughout pregnancy in normal women. J. clin. Endocr. 40, 93-101 (1975)

21. Lubchenco, L. O., Hansman, C., Backstom, L.: Factors influencing fetal growth. In: Aspects of prematurity and dys- maturity (eds. J. H. P. Jonxis, H. K. A. Visser, J. A. Troelstra), pp. 149-166. Leiden: H. E. Stenfert Kroese N. V. 1968

22. De Hertogh, R.: Radioimmunoassay of estrone and estradiol- $17 \beta$ in peripheral plasma of pregnant and non-pregnant women. J. Ster. Biochem. 4, 75-84 (1973)

23. Thomas, K., Beckers, C., Ferin, J. In: Gonadotropins (eds. B. B. Saxena, G. Beling, L. Gandy), p. 377. New York: Wiley-Interscience 1972

24. Ajabor, L. N., Yen, S. S. C.: Effect of sustained hyperglycaemia on the levels of human chorionic somatomammotrophin in mid-pregnancy. Amer. J. Obstet. Gynec. 112, 908-911 (1972)

25. Gaspard, U., Sandront, H., Luyckx, A.: Glucose-insulin interaction and the modulation of human placental lactogen (HPL) secretion during pregnancy. J. Obstet. Gynec. Brit. Cwlth. 81, 201-209 (1974)

26. Sybulski, S.: In vitro estrogen biosynthesis from testosterone by homogenates of placentas from normal pregnancies and pregnancies complicated by intrauterine fetal malnutrition and diabetes. Amer. J. Obstet. Gynec. 105, 1055-1062 (1969)

27. Lehmann, W.D., Misinger, J., Lauritzen, C. H.: Umwandlungsrate von $4{ }^{14} \mathrm{C}$ Dehydroepiandrosteron in Oestron und Oestradiol- $17 \beta$ durch normale sowie Gestose- und Diabetes Placenten. Arch. Gynäk. 210, 49-60 (1971)

28. Townsley, J. D., Rubin, E. J., Crystle, C. D.: Evaluation of placental 3-sulfatase and aromatase activities as regulators of estrogen production in human pregnancy. Amer. J. Obstet. Gynec. 117, 345-350 (1973)

29. Lauritzen, C. H.: Dynamic tests of feto-placental function and endocrine therapy. In: Hormonal investigations in human pregnancy (ed. R. Scholler), pp. 399-418. Paris: SEPE 1974

30. Siiteri, P. K., Mc Donald, P. C.: Placental estrogen biosynthesis during human pregnancy. J. clin. Endocr. 26, 751-761 (1966)

31. Bolte, E., Wiquist, N., Diczfalusy, E.: Metabolism of dehydroepiandrosterone and dehydroepiandrosterone sulphate by the human foetus at midpregnancy. Acta endocr. (Kbh.) 52, 583-597 (1966)

32. Jungmann, R. A., Schweppe, J. S.: Biosynthesis and metabolism of neutral steroids by human midterm placenta and fetal liver. J. clin. Endocr. 27, 1151-1160 (1967)

33. Chattoraj, S. C., Carroll, C. J., Turner, A. K., Gillespie, L., Pinkus, J. L., Charles, D.: Carbohydrate intolerance. Its influence on maternal and fetal levels of cortisol and cortisone. Obstet. and Gynec. 44, 646-656 (1974)

34. Bech, K.: Morphology of the fetal adrenal cortex, and maternal urinary oestriol excretion in pregnancy. Acta obstet. gynec. scand. 50, 215-221 (1971)

35. Naeye, R. L.: Infants of diabetic mothers: A quantitative morphologic study. Pediatrics 35, 980-989 (1965)

36. Cleary, R. E., Pion, R. J.: Urinary excretion of $16 \alpha$-hydroxydehydroepioandrosterone and 16-ketoandrostenediol during the early neonatal period. J. clin. Endocr. 28, 372-378 (1968)

37. Booth, M., Elgarf, T. A. R.: Plasma progesterone concentration during the third trimester of diabetic pregnancy. J. Obstet. Gynaec. Brit. Cwlth. 81, 768-776 (1974)

38. Klebe, J. G., Gaede, P.: Serum progesterone in diabetic pregnancy. Acta endocr. (Kbh.) Suppl. 182, 25-34 (1974)

Received: March 11, 1976, and in revised form: June 16, 1976

\section{Dr. R. De Hertogh}

Université Catholique de Louvain

Unité d' Endocrinologie

et de Nutrition

Brusselsestraat 69

B-3000 Louvain

Belgium 